\title{
Literatur Review : Hubungan Pengetahuan Remaja Putri Mengenai Anemia Dengan Kepatuhan Mengkonsumsi Tablet Tambah Darah
}

\author{
Risky Dwi Hayati ${ }^{1 *}$, Ratnawati ${ }^{2}$ \\ ${ }^{1,2}$ Program Studi Sarjana Keperawatan dan Pendidikan Profesi Ners, Universitas Muhammadiyah \\ Pekajangan Pekalongan, Indonesia \\ *email: riskydh15@gmail.com
}

\begin{abstract}
Growth and lack of blood during menstruation will increase the girl's need for iron. It can cause the girls to be very susceptible to anemia. Their knowledge is a very important guiding factor in increasing the compliance of young women in consuming Fe tablets, so that they will not experience anemia. This literature review aimed to determine the correlation between the girl's knowledge of anemia with their adherence to supplemental iron intake. The research method used was correlation with Literature Review data collection. The articles were research using Google Scholar according to keywoards then analyzed using JBI (Joanna Briggs Institute). The results showed that most of the girls had sufficient knowledge of anemia (50.6\% or 133 respondents), and adhered to consume supplemental iron tablets ( $64.9 \%$ or 446 respondents). There was a correlation between knowledge and adherence to supplemental iron intake. The p-value was ranged from $0.000-0.01(<0.05)$. Based on the result, it can be cincluded that there is a correlation between knowledge and adherence to supplemental iron intake.
\end{abstract}

Keywords : Young Women; Knowledge of Anemia; Supplemental iron intake

\section{Abstrak}

Pertumbuhan dan kekurangan darah pada remaja putri saat menstruasi akan meningkatkan kebutuhan zat besi sehingga menyebabkan remaja putri sangat rentan terhadap anemia. Pengetahuan remaja putri merupakan faktor penuntun yang sangat penting dalam meningkatkan kepatuhan remaja putri mengkonsumsi tablet fe, sehingga remaja putri tidak akan mengalami anemia. Literatur Review ini bertujuan untuk mengetahui hubungan pengetahuan remaja putri mengenai anemia dengan kepatuhan mengkonsumsi tablet tambah darah. Metode penelitian yang digunakan adalah penelitian korelasi dengan pengumpulan data Literatur Review, dengan pencarian literatur menggunakan Google Schoolar sesuai dengan kata kunci kemudian dianalisa sesuai dengan kriteria inklusi dan ditemukan 5 artikel dan kemudian ditelaah menggunakan JBI (Joanna Briggs Institute). Hasil analisa dari kelima artikel remaja putri memiliki pengetahuan anemia yang cukup sebanyak $133(50,6 \%)$, patuh mengkonsumsi tablet tambah darah 446 (64,9\%), dan terdapat hubungan antara pengetahuan remaja putri dengan kepatuhan mengkonsumsi tablet tambah darah dengan $p$ value $=0,000-0,01(<0,05)$. Berdasarkan hasil literatur review menunjukkan ada hubungan pengetahuan dengan kepatuhan mengkonsumsi tablet tambah darah.

Kata kunci: Remaja Putri; Pengetahuan Anemia; Kepatuhan Konsumsi Tablet Tambah Darah 


\section{Prosiding Seminar Nasional Kesehatan 2021 Lembaga Penelitian dan Pengabdian Masyarakat Universitas Muhammadiyah Pekajangan Pekalongan}

\section{Pendahuluan}

Anemia pada remaja dapat mempengaruhi efisiensi kerja sekolah atau penurunan kemampuan belajar. Kurangnya semangat belajar dan konsrentrasi dapat mengakibatkan penurunan daya tahan tubuh dan menyebabkan remaja rentan terhadap penyakit. Remaja putri memerlukan perhatian khusus dalam hal kesahatan, dikarenakan pertumbuhan dan kurangnya darah pada remaja putri saat sedang menstruasi akan meningkatkan kebutuhan zat besi sehingga menyebabkan remaja putri sangat rentan terhadap anemia [1]. Hal ini tentunya tidak baik bagi perkembangan generasi muda, karena akan mempengaruhi kemampuan daya ingat sehingga prestasi akademik menjadi kurang optimal.

Remaja putri memiliki risiko lebih tinggi mengalami anemia. Peningkatan kebutuhan besi ini terutama disebabkan oleh hilangnya zat besi pada saat menstruasi [2]. Kekurangan zat besi akan menurunkan daya tahan tubuh, sehingga mengakibatkan penurunan produktivitas. Asupan zat besi didapat dari makanan sumber protein hewani, seperti ikan, daging dan hati. Namun, tidak semua orang bisa mengkonsumsi makanan seperti ini, sehingga perlu mengkonsumsi zat tambahan dari tablet tambah darah / TTD [3].

Kementerian kesehatan memaparkan perihal pemberian Tablet Tambah Darah pada remaja putri dan wanita usia subur / WUS, pemberian TTD kepada remaja putri melalui UKS / $M$ dengan menentukan tanggal / hari minum TTD bersama, di institusi pendidikan SMP dan SMA atau sederajat [4]. Berdasarakan Profil Kesehatan Indonesia tahun 2018, diketahui pada tahun 2018 angka cakupan tablet tambah darah yang diberikan kepada remaja putri di Indonesia adalah 48,52\%. Hal tersebut telah mencapai target $25 \%$ yang ditetapkan dalam Renstra 2018. Persentase di provinsi Jawa Tengah adalah 56,52\%. Provinsi dengan cakupan TTD remaja perempuan tertinggi adalah Bali (92\%) dan terendah adalah Kalimantan Barat (9,62\%). Sebanyak tujuh provinsi belum memenuhi target Renstra 2018 [3].

Kurangnya pengetahuan remaja mengenai anemia menyebabkan remaja kurang memahami mengenai anemia. Pengetahuan remaja putri mengenai anemia baru sampai pada tahap tahu. Dan tidak diikuti dengan pengaplikasian dalam kehidupan sehari-hari, seperti makan makanan yang banyak mengandung zat besi [5]. Dalam penelitian Sari et al., menyatakan bahwa pengetahuan remaja putri merupakan faktor penuntun yang sangat penting dalam meningkatkan kepatuhan remaja putri mengkonsumsi tablet fe, sehingga remaja putri tidak akan mengalami anemia [1]. Hasil ini menunjukkan bahwa semakin baik pengetahuan remaja putri semakain tinggi kepatuhan dalam mengkonsumsi tablet Fe. Penelitian Agustina menyebutkan bahwa terdapat responden dengan pengetahuan anemia gizi kategori baik 68 orang (58\%) patuh dalam mengkonsumsi TTD, sedangkan responden yang berpengetahuan cukup hanya 49 orang $(41,9 \%)$ patuh dalam mengkonsumsi TTD, dapat disimpulkan bahwa ada hubungan signifikan antara pengetahuan anemia gizi besi dengan kepatuhan dalam mengkonsumsi TTD [6].

Tujuan penelitian ini untuk mengetahui hubungan pengetahuan remaja putri mengenai anemia dengan kepatuhan mengkonsumsi tablet tambah darah. 


\section{Prosiding Seminar Nasional Kesehatan Lembaga Penelitian dan Pengabdian Masyarakat Universitas Muhammadiyah Pekajangan Pekalongan

\section{Metode}

Metode penelitian yang digunakan adalah penelitian korelasi dengan pengumpulan data Literatur Review, dengan pencarian literatur menggunakan Google Schoolar sesuai dengan kata kunci kemudian dianalisa sesuai dengan kriteria inklusi dan ditemukan 5 artikel dan kemudian ditelaah menggunakan JBI (Joanna Briggs Institute).

\section{Hasil dan Pembahasan Hasil}

Instrumen penelitian yang digunakan dalam penelitian ini adalah JBI (Joanna Briggs Institute). $J B I$ yang digunakan dalam penelitian ini adalah $J B I$ dengan jenis studi cross sectional dan terdapat 8 pertanyaan [7]. Terdapat 5 artikel yang dinilai dan dianlisis kualitas metodologinya menggunakan JBI. Terdapat 5 artikel yang sesuai dengan kriteria inklusi untuk dimasukkan dalam sampel yang sudah diidentifikasi dengan jelas, yaitu membahas tentang pengetahuan anemia pada remaja putri dengan kepatuhan mengkonsumsi tablet tambah darah. Dalam hasil artikel dijelaskan bahwa pengetahuan berhubungan dengan kepatuhan mengkonsumsi tablet tambah darah.

Dari kelima artikel sudah dijelaskan secara rinci subjek penelitian dan latarnya. Dari kelima artikel variabel diukur dengan cara yang valid dan dapat diandalkan yaitu menggunakan kuesioner pengetahuan dan kepatuhan, namun kuesioner tersebut berbeda-beda untuk setiap artikel. Untuk artikel Wahyuningsih \& Uswatun menggunakan kesioner dan lembar observasi berupa kartu suplementasi gizi [8]. Artikel Tirthawati et al., menggunakan wawancara dimana untuk variabel pengetahuan terdapat 15 pertanyaan dan untuk kepatuhan 4 pertanyaan [9]. Artikel Dubik et al., menggunakan kuesioner dari penelitian terdahulu yang diadaptasi dimana variabel pengetetahuan terdapat 16 pertanyaan dan untuk kepatuhan 9 pertanyaan [10]. Sedangkan 2 artikel tidak menjelaskan kuesioner secara jelas yaitu artikel dari Saridewi \& Ekawati dan Andani et al., [11],[12]. Dari kelima artikel tidak terdapat faktor perancu.

\section{Karakteristik responden}

Berdasarkan kelima artikel didapat hasil analisis dari karakteristik responden seperti tabel 1.

Tabel 3.1 Hasil Analisis Karakteristik Responden

\begin{tabular}{|c|c|c|c|c|c|}
\hline \multicolumn{6}{|c|}{ Karakteristik Responden } \\
\hline \multirow[t]{2}{*}{ Penulis. } & \multirow[t]{2}{*}{ Tahun. } & \multicolumn{3}{|c|}{ Umur } & \multirow{2}{*}{$\begin{array}{c}\text { Peadidikan } \\
\text { SMA }\end{array}$} \\
\hline & & 10-15 & $16-20$ & SMP & \\
\hline $\begin{array}{l}\text { Astri Wabyuningsih } \\
\text { \& Anna Uswatum }\end{array}$ & 2019 & NM & NM & NM & 41 \\
\hline $\begin{array}{l}\text { Wisdyana Saridewi } \\
\text { \& Kartika Ekawati }\end{array}$ & 2020 & NM & NM & NM & 76 \\
\hline $\begin{array}{l}\text { Sari Jirthawati et al. } \\
\text { Yuke Andani et al. }\end{array}$ & 2019 & 39 & 34 & NM & 73 \\
\hline \multirow[t]{3}{*}{$\begin{array}{c}\text { S. Daaian Dubik et } \\
\text { al. }\end{array}$} & 2020 & $\begin{array}{c}(53,4 \%) \\
\text { NM }\end{array}$ & $\begin{array}{c}(46,6 \%) \\
\text { NM }\end{array}$ & 73 & NM \\
\hline & 2019 & 338 & 86 & 424 & NM \\
\hline & & $(79,7 \%)$ & $(20.3 \%)$ & & \\
\hline \multirow{2}{*}{\multicolumn{2}{|c|}{ Total masing-masing }} & 377 & 120 & & 190 \\
\hline & & $(75.2 \%)$ & $(24,1 \%)$ & & $(27.7 \%)$ \\
\hline \multicolumn{2}{|c|}{ Total responden } & & 497 & & 687 \\
\hline
\end{tabular}




\section{Prosiding Seminar Nasional Kesehatan Lembaga Penelitian dan Pengabdian Masyarakat Universitas Muhammadiyah Pekajangan Pekalongan}

Hasilnya bahwa sebagian besar usia responden pada kisaran usia 10-15 tahun sebanyak 377 (75,9\%). Pada karakteristik pendidikan didapatkan bahwa sebagian besar pendidikan responden pada tingkat SMP yaitu sebanyak 497 (72,3\%).

\section{Tingkat Pengetahuan Anemia}

Tabel 3.2 Hasil Analisis Pengetahuan Responden Kategori Baik, Cukup, dan Kurang

\begin{tabular}{|c|c|c|c|c|c|c|c|}
\hline \multicolumn{2}{|l|}{ Artikel } & \multicolumn{6}{|c|}{ Pengetahuan } \\
\hline \multirow{2}{*}{$\begin{array}{c}\text { Penulis } \\
\text { Astri Wahyuningsih } \\
\text { \& Anna Uswatun }\end{array}$} & \multirow{2}{*}{$\begin{array}{c}\text { Tahun } \\
2019\end{array}$} & \multicolumn{2}{|c|}{ Baik } & \multicolumn{2}{|c|}{ Cukup } & \multicolumn{2}{|c|}{ Kurang } \\
\hline & & 19 & $46,3 \%$ & 20 & $48,8 \%$ & 2 & $4,9 \%$ \\
\hline $\begin{array}{l}\text { Wisdyana Saridewi } \\
\text { \& Kartika Ekawati }\end{array}$ & 2019 & 33 & $43,4 \%$ & 31 & $40,8 \%$ & 12 & $\begin{array}{c}15,8 \\
\%\end{array}$ \\
\hline Sari Tirthawati et al. & 2020 & 33 & $45,2 \%$ & 40 & $54,8 \%$ & 0 & 0 \\
\hline Yuke Andani et al. & 2020 & 25 & $34,2 \%$ & 42 & $57,5 \%$ & 6 & $8,2 \%$ \\
\hline $\begin{array}{l}\text { Total masing- } \\
\text { masing }\end{array}$ & & 110 & $41,8 \%$ & 133 & $50,6 \%$ & 20 & $7,6 \%$ \\
\hline Total Responden & & & & & & & \\
\hline
\end{tabular}

Berdasarkan hasil analisis data 4 artikel yang direview dari tingkat pengetahuan anemia didapatkan bahwa paling banyak responden memiliki tingkat pengetahuan anemia yang cukup yaitu $133(50,6 \%)$ dan paling sedikit pengetahuan kurang dengan jumlah $20(7,6 \%)$.

Tabel 3. Hasil Analisis Pengetahuan RespondenKategori Baik dan Kurang

$$
\text { Artikel Pengetahuan }
$$

\begin{tabular}{|c|c|c|c|c|c|}
\hline Penulis & Tahun & & Baik & & Kurang \\
\hline S. Daajan Dubik et al. & 2019 & 83 & $3,2 \%$ & 41 & $6,8 \%$ \\
\hline Total responden & & & & 424 & \\
\hline
\end{tabular}

Satu artikel dari Dubik et al., (2019) membagi kategori pemgetahuan menjadi 2 kategori yaitu Baik dan Buruk, Berdasarkan analisis artikel tersebut bahwa responden yang memiliki pengetahuan anemia yang baik sebanyak $183(43,2 \%)$ dan kurang sebanyak 241 (56,8\%). Berdasarkan kelima artikel yang telah direview mempunyai kategori yang berbeda dan didominasi pengetahuan yang cukup sebanyak 133 $(50,6 \%)$ responden. 


\section{Prosiding Seminar Nasional Kesehatan Lembaga Penelitian dan Pengabdian Masyarakat Universitas Muhammadiyah Pekajangan Pekalongan}

\section{Kepatuhan Mengkonsumsi Tablet Tambah Darah}

Tabel 3.3 Kepatuhan Mengkonsumsi Tablet Tambah Darah

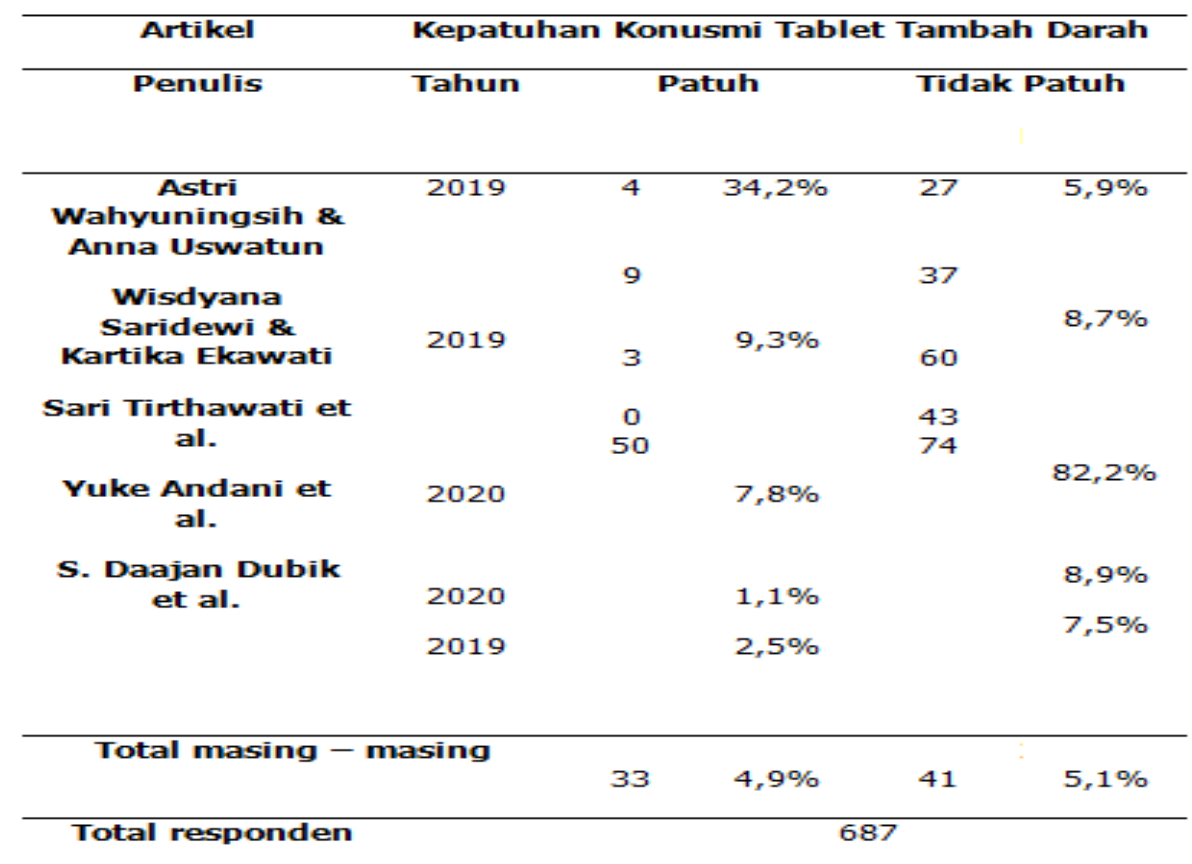

Hasil Analisis Kepatuhan Mengkonsumsi Tablet Tambah Darah Responden. Hasilnya sebagian sebagian besar responden patuh mengkonsumsi tablet tambah darah yaitu sebanyak $433(64,9 \%)$ responden.

\section{Hubungan Pengetahuan Anemia dengan Kepatuhan Mengkonsi Tablet Tambah Darah}

Tabel 3.4 Hasil Analisis Hubungan Pengetahuan Anemia dengan Kepatuhan Mengkonsumsi Tablet Tambah Darah

\begin{tabular}{|c|c|c|c|}
\hline Penulis & Tahun & Hasil (p value) & Keterangan \\
\hline $\begin{array}{c}\text { Astri } \\
\text { Wahyuningsih \& } \\
\text { Anna Uswatun }\end{array}$ & 2019 & $p=0,000$ & $\begin{array}{c}\text { Ada hubungan antara remaja putri } \\
\text { tentang anemia dengan kepatuhan } \\
\text { mengkonsumsi tablet tambah } \\
\text { darah }\end{array}$ \\
\hline $\begin{array}{c}\text { Wisdyana } \\
\text { Saridewi \& } \\
\text { Kartika Ekawati }\end{array}$ & 2019 & $p=0,000$ & $\begin{array}{c}\text { Ada hubungan yang bermakna } \\
\text { antara pengetahuan dengan } \\
\text { kepatuhan }\end{array}$ \\
\hline $\begin{array}{c}\text { Sari Tirthawati } \\
\text { et al. }\end{array}$ & 2020 & $p=0,004$ & $\begin{array}{l}\text { Ada hubungan antara } \\
\text { pengetahuan dengan kepatuhan } \\
\text { mengkonsumsi tablet besi folat }\end{array}$ \\
\hline $\begin{array}{c}\text { Yuke Andani et } \\
\text { al. }\end{array}$ & 2020 & $p=0,013$ & $\begin{array}{c}\text { Ada hubungan antara } \\
\text { pengetahuan terhadap konsumsi } \\
\text { tablet tambah darah }\end{array}$ \\
\hline
\end{tabular}




\section{Prosiding Seminar Nasional Kesehatan 2021 Lembaga Penelitian dan Pengabdian Masyarakat Universitas Muhammadiyah Pekajangan Pekalongan}

\begin{tabular}{|c|c|c|c|}
\hline Penulis & Tahun & Hasil (p value) & Keterangan \\
\hline $\begin{array}{c}\text { S. Daajan Dubik } \\
\text { et al. }\end{array}$ & 2019 & $p=0,01$ & $\begin{array}{c}\text { Ada hubungan antara } \\
\text { pengetahuan anemia dengan } \\
\text { kepatuhan mengkonsumsi tablet } \\
\text { tambah darah }\end{array}$ \\
\hline
\end{tabular}

Rerata

$p=0,000-0,01<0,05$

Berdasarkan hasil analisis artikel yang direview bahwa dari kelima artikel tersebut, pada variabel tingkat pengetahuan remaja putri dan kepatuhan mengkonsumsi tablet tambah terdapat hubungan antara pengetahuan anemia dengan kepatuhan mengkonsumsi tablet tambah darah dengan nilai $p$ value $=0,000-0,01$ atau $<0,05$.

\section{Pembahasan}

\section{Karakteristik responden}

Sebagian besar pada usia 10-15 tahun yaitu sebanyak 377 responden atau $75,9 \%$. Usia tersebut merupakan tahap pertumbuhan dan perkembangan tercepat kedua setelah bayi dalam siklus kehidupan, baik pertumbuhan fisik, psikologis maupun intelektual [6]. Menurut Dieny (2014) pada masa ini pengearuh teman sebaya semakin meningkat, memahami orang lain dan menjalin persahabtan dengan teman yang sifatnya relatif sama dengan dirinya [2].

Karakteristik responden berdasarkan pendidikan didapatkan dari kelima artikel bahwa sebagian besar responden berpendidikan SMP yaitu sebanyak 497 responden atau $72,4 \%$. Teori menyatakan faktor-faktor yang dapat mempengaruhi pengetahuan yaitu tingkat pendidikan, informasi, pengalaman, budaya dan sosial ekonomi [13].

\section{Pengetahuan anemia}

Hasli review untuk variabel pengetahuan anemia didapatkan data bahwa responden memiliki tingkat pengetahuan yang cukup sebanyak 133 responden atau $50,6 \%$. Hal ini sejalan dengan penelitian Nurwanti dengan hasil penelitian menunjukkan bahwa mayoritas responden memiliki pengetahuan anemia yang cukup sebesar 22 atau 37,3\% responden [14]. Dari kelima artikel yang direview dapat disimpulkan bahwa remaja putri memiliki pengetahuan yang cukup mengenai anemia. Berbeda dari penelitian yang dilakukan Hamranani et al., (2018) dengan hasil penelitian menunjukkan bahwa sebagian besar responden yaitu $50(60,2 \%)$ responden memiliki pengetahuan yang baik tentang anemia [15]. Pengetahuan adalah hasil dari tau, dan terjadi setelah seseorang melakukan penginderaan terhadap suatu objek tertentu. Tanpa pengetahuan seseorang tidak mempunyai dasar untuk mengambil keputusan dan menentukan tindakan terhadap masalah yang dihadapi [16]. Pengetahuan dalam hal ini dapat disebabkan oleh informasi yang diperoleh responden. Seseorang yang mendapatkan informasi lebih banyak akan menambah pengetahuan 


\section{Prosiding Seminar Nasional Kesehatan Lembaga Penelitian dan Pengabdian Masyarakat Universitas Muhammadiyah Pekajangan Pekalongan}

yang lebih luas [13]. Penelitian Sari et al., menyatakan pengetahuan yang baik tentang anemia merupakan salah satu faktor penentu kepatuhan dalam mengkonsumsi tablet tambah darah [1]. Remaja putri menyadari bahwa remaja putri lebih rentan untuk menderita anemia. Mencegah anemia tidak cukup jika hanya mengkonsumsi makanan yang mengandung zat besi nabati ataupun hewani, harus diseimbangi juga dengan minum tablet tambah darah [17].

\section{Kepatuhan mengkonsumsi tablet tambah darah}

Hasil analisa dari artikel didapatkan bahwa sebagian besar responden patuh terhadap mengkonsumsi tablet tambah darah yaitu 446 responden $(64,9 \%)$. Hal ini sejalan dengan penelitian Yuniarti et al., Bahwa sebanyak 20 (40,8\%) responden tidak patuh mengkonsumsi tablet zat besi 1 kali sehari selama 6 minggu, yang artinya $59,2 \%$ responden atau lebih setengahnya patuh mengkonsumsi tablet zat besi. Tablet zat besi (Fe) adalah tablet mineral yang dibutuhkan oleh tubuh untuk membentuk sel darah merah atau hemoglobin [19]. Mengkonsumsi tablet tambah darah dapat mencegah anemia zat besi pada remaja putri. Para remaja putri minum satu tablet tambah darah seminggu sekali. Kegiatan ini merupakan implementasi dari peraturan Menteri Kesehatan Nomor 88 tahun 2014 yang mengatur tentang standar pemberian tablet tambah darah bagi wanita usia subur dan ibu hamil, serta surat edaran dari Direktur Kesehatan Masyarakat Kementerian Kesehatan Republik Indonesia Nomor HK.03.03/V/0595/2016 tentang pemberian TTD [20]. Jika tablet tambah darah diminum teratur dan sesuai resep, anemia gizi dapat dicegah dan diatasi. Menurut Irianti \& Sahiroh ada beberapa faktor yang berhubungan dengan konsumsi tablet tambah darah yaitu kurang dapat diterimanya rasa tablet tambah darah yang menjadi salah satu faktor yang mempengaruhi kepatuhan dalam mengkonsumsi tablet tambah darah [21].

\section{Hubungan pengetahuan anemia dengan kepatuhan mengkonsumsi tablet tambah darah}

Hubungan pengetahuan dengan kepatuhan mengkonsumsi tablet tambah darah berdaskan artikel yang telah direview dengan hasil rerata $p=0,000-0,01(<0,05)$. Dapat disimpukan bahwa adanya hubungan pengetahuan anemia dengan kepatuhan mengkonsumsi tablet tambah darah. Hal ini sejalan dengan penelitian Wahyuningsih \& Rohmawati yang menunjukkan adanya hubungan pengetahuan dengan kepatuhan konsumsi tablet tambah darah di SMP N 1 Karangnomgko dengan uji statistik chi square didapatkan nilai $\mathrm{p}$ value $=0,001$ [22]. Data tersebut menunjukkan bahwa jika responden memiliki tingkat pengetahuan yang baik maka responden patuh terhadap konsumsi tablet tambah darah. Begitu pula sebaliknya jika pengetahuan responden tentang anemia kurang, maka akan banyak responden yang tidak patuh mengkonsumsi tablet tambah darah sehingga anemia pada remaja putri semakin meningkat. Menurut penelitian Sari et al., pengetahuan berhubungan dengan kepatuhan karena kepatuhan merupakan domain yang penting terbentuknya perilaku. Perilaku akan langgeng jika didasari oleh pengetahuan. Perilaku diperoleh dari pengindraan remaja terhadap informasi kesehatan akan berpengaruh terhadap 


\section{Prosiding Seminar Nasional Kesehatan $\mathbf{2 0 2 1}$ Lembaga Penelitian dan Pengabdian Masyarakat Universitas Muhammadiyah Pekajangan Pekalongan}

perilaku remaja untuk menjaga kesehatan terutama untuk terhindar dari anemia maka remaja akan patuh untuk minum tablet tambah darah [1].

\section{Kesimpulan}

Berdasarkan karakteristik, sebagian besar responden pada usia 10-15 dan pendidikan responden sebagian besar berpendidikan SMP. Berdasarkan pengetahuan, setengah lebih responden memiliki pengetahuan anemia yang cukup. Berdasarkan kepatuhan mengkonsumsi tablet tambah darah, sebagian besar remaja putri patuh dalam mengkonsumsi tablet tambah darah. Dari kelima artikel yang di literatur review, lima artikel menyatakan terdapat hubungan antara pengetahuan remaja putri dengan kepatuhan mengkonsumsi tablet tambah darah dengan $p$ value $=0,000-0,01$ (< $0,05)$.

\section{Referensi}

[1] D. P. Sari et al., "Hubungan Pengetahuan dan Sikap dengan Kepatuhan Minum Tablet Fe pada Remaja Putri," 12th Univ. Res. Colloqium 2020, no. 4, pp. 328336, 2020.

[2] F. F. Dieny, Permasalahan gizi Pada Remaja Putri. Yogyakarta: Yogyakarta: Graha Ilmu, 2014.

[3] Kemenkes, profil kesehatan indonesia 2018. Jakarta: Kementerian Kesehatan RI, 2019.

[4] Kemenkes, "Surat Edaran tentang Pemberian Tablet Tambah Darah Pada Remaja Putri dan Wanita Usia Subur," Direktorat Jenderal Kesehatan Masyarakat Kementerian Kesehatan Ri, 2016.

[5] N. N. Fajriyah and M. L. H. Fitriyanto, "Gambaran Tingkat Pengetahuan Tentang Anemia Pada Remaja Putri," J. IImu Kesehat., vol. IX, no. 1, pp. 1-6, 2016.

[6] Agustina, "Analisis Pengetahuan Terhadap Kepatuhan Remaja Putri Dalam Mengkonsumsi Tablet Tambah Darah Untuk Pencegahan Dan Penanggulangan Anemia Gizi Besi," J. IIm. Kesehat. Masy., vol. 11, pp. 269-276, 2019.

[7] I. J. Briggs, Joanna Briggs Institute Reviewers 'Manual: 2016 edition. Australia: Institut Joanna Briggs, 2016.

[8] A. Wahyuningsih and A. Uswatun, "Hubungan Pengetahuan Tentang Anemia Dengan Kepatuhan Mengkonsumsi Tablet Tambah darah Remaja Putri Di SMA Negeri 1 Karanganom," J. Involusi Kebidanan, vol. 9, pp. 4-13, 2019.

[9] S. Tirthawati et al., "Pengetahuan, sikap Remaja Putri dan Dukungan Petugas Kesehatan terhadap Konsumsi Tablet Besi Folat SMKN 1 Bangsri Jepara," J. Gizi Unimus, vol. 9, pp. 201-214, 2020, [Online]. Available: http://jurnal.unimus.ac.id.

[10] S. D. Dubik et al., "Compliance with Weekly Iron and Folid Acid Suplementation and Its Associated Factors among Adolescent Girls in Tamale Metropolis of Ghana," Hindawi J. Nutr. Metab., vol. 2019, 2019.

[11] W. Saridewi and K. Ekawati, "Hubungan Pengetahuan dengan Kepatuhan Mengkonsumsi Tablet Tambah Darah di SMAN 1 Ngamprah," 1st Procceding Publ. Creat. Res. Med. Lab. Technol. DIV, vol. 1, 2019. 


\section{Prosiding Seminar Nasional Kesehatan Lembaga Penelitian dan Pengabdian Masyarakat Universitas Muhammadiyah Pekajangan Pekalongan}

[12] Y. Andani et al., "Hubungan Pengetahuan dan Sikap Remaja Putri Terhadap Konsumsi Tablet Tambah Darah (TTD) Di SMP Negeri 1 Kepahiang," J. Kebidanan Besurek, vol. 5, pp. 55-62, 2020.

[13] T. Lestari, Kumpulan Teori untuk Kajian Pustaka Penelitian Kesehatan. Yogyakarta: Yogyakarta: Nuha Medika, 2015.

[14] Nurwanti, "Hubungan Pengetahuan Anemia Terhadap Kepatuhan Mengkonsumsi Tablet Fe Pada Siswi Kelas X SMA Negeri 1 Gamping Tahun 2019," Universitas 'Aisyiyah Yogyakarta, 2019.

[15] S. S. T. Hamranani et al., "Hubungan Pengetahuan dan Sikap Dengan Kepatuhan Minum Tablet Fe Pada Remaa Putri Kelas X Di SMK N 1 Klaten," J. IImu Keperwatan, vol. 8, 2018.

[16] T. E. Purwoastuti and E. S. Walyani, Perilaku \& Softskills Kesehatan. Yogyakarta: Yogyakarta : Pustaka Baru Press, 2015.

[17] N. P. K. C. Dewi et al., "Gambaran Pengetahuan Tentang Konsumsi Tablet Fe Pada Remaja Putri Di SMP Negeri 2 Bandungan," Univ. Ngudi Waluyo, 2019.

[18] Yuniarti, Rusmilawaty, and T. Tunggal, "Hubungan Antara Kepatuhan Minum Tablet Fe Dengan Kejadian Anemia pada Remaja Putri Di MA Darul Imad Kecamatan Tatah Makmur Kabupaten Banjar," J. Publ. Kesehat. Masy. Indones., vol. 2, no. 1, pp. 31-36, 2015.

[19] Kemenkes, "Pentingnya Konsumsi Tablet Fe Bagi Ibu Hamil," Direktorat Promosi Kesehatan dan Pemberdayaan Masyarakat Kementerian Kesehatan RI, 2018. .

[20] Kemenkes, "Menkes Semangati Remaja Putri Gorontalo Terbebas dari Anemia," Biro Komunikasi dan Pelayanan Masyarakat Kementerian Kesehatan RI, 2018. .

[21] S. Irianti and Sahiroh, "Gambaran Faktor Konsumsi Tablet Tambah Darah Pada Remaja Putri," J. IIm. Kebidanan, vol. 6, no. 2, pp. 92-97, 2019.

[22] A. Wahyuningsih and W. Rohmawati, "Hubungan Pengetahuan Dengan Kepatuhan Konsumsi Tablet Tambah Darah Pada Remaja Putri Di SMP N 1 Karangnongko," J. IImu Kebidanan, vol. 10, pp. 8-12, 2020. 